\title{
Continental European Involvement in the Eighteenth-Century British Empire
}

\author{
Stephen Conway
}

This lecture brings together historical approaches usually pursued separately, or even antagonistically. Recent scholarship attempting to place eighteenth-century Britain in a wider context has tended to take one of two paths: the imperial or the European, the latter often linked to a new interest amongst British historians in the Hanoverian connection. ${ }^{1}$ One of my objectives is to demonstrate that the imperial and the European need not be seen as alternative perspectives. An obvious if easily overlooked point is that empire and Europe overlapped: Ireland was both part of the metropolitan core and a colony, while the Mediterranean outposts of Gibraltar and Minorca were as much imperial possessions as the North American provinces, the West Indian islands, and the Asian holdings of the East India Company. ${ }^{2}$ But the complementarity of Europe and empire perhaps comes most clearly into focus when we consider continental European involvement in British territories across the globe. ${ }^{3}$

1 For the imperial, see, e.g., Kathleen Wilson, The Island Race. Englishness, Empire, and Gender in the Eighteenth Century, London 2002; Kathleen Wilson (Hg.), A New Imperial History. Culture, Identity, and Modernity in Britain and the Empire, 1660-1840, Cambridge 2004; Miles Ogborn, Global Lives. Britain and the World, 1550-1800, Cambridge 2008; Emma Rothschild, The Inner Life of Empires. An Eighteenth-Century History, Princeton 2011; For the European turn, see, e.g., Andrew C. Thompson, Britain, Hanover, and the Protestant Interest, 1688-1756, Woodbridge 2006; Brendan Simms / Torsten Riotte (Hg.), The Hanoverian Dimension in British History, 1714-1837, Cambridge 2007; Marie Peters, Early Hanoverian Consciousness, Empire or Europe?, in: English Historical Review 122 (2007), S. 632-668; Tony Claydon, Europe and the Making of England, 1660-1760, Cambridge 2007; Stephen Conway, Britain, Ireland, and Continental Europe in the Eighteenth Century. Similarities, Connections, Identities, Oxford 2011.

2 For the influence of the European parts of the empire on the governing of newly conquered Canada, see Stephen Conway, The Consequences of the Conquest. Quebec and British Politics, 1760-1774, in: Phillip Buckner / John G. Reid (Hg.), Revisiting 1759. The Conquest of Canada in Historical Perspective, Toronto 2012, S. 141-165.

3 Continental European is used here as a short-hand for all non-British and non-Irish Europeans. It includes inhabitants of islands such as Minorca and Corsica, even though they were not, strictly speaking, continental. 
Historians are beginning to appreciate the similarities between the different $\mathrm{Eu}$ ropean overseas empires, and even their interconnectedness. ${ }^{4}$ But no scholar - as far as I know - has attempted to bring out the European character of Britain's empire by systematically exploring the many ways in which other Europeans contributed to its expansion, consolidation, and defence. The first section of the lecture accordingly surveys the various continental European inputs in the second half of the eighteenth century, where possible conveying an impression of their scale. The choice of period is deliberate: historians often claim that from the seventeen-fifties the British became more nationally and imperially conscious; ${ }^{5}$ I want to demonstrate that an empire usually depicted as a great national enterprise, and the focus of much national pride, depended to a remarkable degree on continental European assistance.

While this is a transnational story, we cannot understand it without looking at the actions and attitudes of national politicians and administrators. Enthusiasts for transnational history often present it as an antidote to narrowly national history; again, I want to show that divergent approaches can fruitfully be brought together. In the second part of the lecture I hope to establish that British governments saw no inconsistency in encouraging some forms of continental European involvement in the empire and attempting to block or limit others. Their decisions about which forms of involvement should be encouraged, and which should not, reflected the political and economic orthodoxy of the time, usually described by historians as mercantilism. Despite long-running debates about whether the concept obscures more than it reveals, mercantilism remains a useful shorthand term for a wide range of government measures - going far beyond trade regulation - designed to promote national prosperity and power by preserving and enhancing resources to compete more effectively with other states. ${ }^{6}$

4 A pioneer in this respect is Holden Furber, Rival Empires of Trade in the Orient, 1600-1800, Oxford 1976; for more recent examples, see J. H. Elliott, Empires of the Atlantic World. Britain and Spain in America, 1492-1830, New Haven 2006; Eliga H. Gould, Entangled Histories, Entangled Worlds. The English-Speaking Atlantic as a Spanish Periphery, in: American Historical Review 112 (2007), S. 764-786; Jack P. Greene / Philip D. Morgan (Hg.), Atlantic History. A Critical Appraisal, New York 2009.

5 See, e. g., P. J. Marshall's essays, Cornwallis Triumphant, War in India and the British Public in the Late Eighteenth Century, in: Lawrence Freedman / Paul Hayes / Robert O’Neill (Hg.), War, Strategy, and International Politics. Essays in Honour of Sir Michael Howard, Oxford 1992, S. 57-74; P. J. Marshall, A Nation Defined by Empire, 1755-1776, in: Alexander Grant / Keith J. Stringer (Hg.), Uniting the Kingdom? The Making of British History, London 1995, S. 208-222; Linda Colley, Britons, Forging the Nation, 1707-1837, New Haven 1992, chs. 2 and 3; Kathleen Wilson, The Sense of the People. Politics, Culture, and Imperialism in England, 1715-1785, Cambridge 1995; Eliga H. Gould, The Persistence of Empire. British Political Culture in the Age of the American Revolution, Chapel Hill 2000; Bob Harris, Politics and the Nation. Britain in the Mid-Eighteenth Century, Oxford 2002.

6 For scepticism, see, e. g., D. C. Coleman, Eli Heckscher and the Idea of Mercantilism, in: D. C. Coleman (Hg.), Revisions of Mercantilism, London 1969, S. 92-117; for recent emphasis on division over political economy, see Steve Pincus, Rethinking Mercantilism. Political Economy, the British Empire, and the Atlantic World in the Seventeenth and Eighteenth Centuries, in: William \& Mary Quarterly, 3rd series, 69 


\section{I.}

We begin, then, with a brief survey of continental European involvement in the empire. Capital investment is perhaps an appropriate place to start. The British national debt supported far more than imperial defence and expansion, but as an increasingly large portion of the British armed forces were deployed in the extra-European world from the middle of the century, we can reasonably say that the national debt underwrote a good deal of British imperial activity. ${ }^{7}$ Between 1760 and the late seventeen-eighties, according to a recent calculation, more than $£ 20$ million were put in British public funds by overseas investors, or about sixteen per cent of the total. ${ }^{8}$ This proportion was probably smaller than earlier in the century, when the Dutch stake alone amounted to about fifteen per cent, but even by the seventeen-nineties foreign investment was still far from negligible. ${ }^{9}$ Another piece of detailed scholarship reveals that European holdings in the stock of the British East India Company were particularly impressive: in the seventeen-sixties they amounted to some thirty per cent of all accounts. ${ }^{10}$ Nor was continental European investment confined to the public funds and the great chartered companies. Private individuals, trying to secure profits in British overseas possessions, also sought European backing. Dutch financiers, such as Hope and Co., of Amsterdam, lent money to British West Indian planters. ${ }^{11}$

European commodities also played a significant part. British slave traders on the west coast of Africa almost certainly used Dutch gunpowder and muskets. ${ }^{12}$ In Asia, senior officers of the British East India Company's army preferred to equip their cavalry with swords of German manufacture rather than comparable British products. ${ }^{13}$ A study of the cargoes of British ships sailing for India has revealed that they often contained continental European manufactures as well as domestically produced ones:

(2012), S. 3-34.

7 For deployments, see J. A. Houlding, Fit for Service. The Training of the British Army, 1715-1795, Oxford 1981, S. 409-413 (Appendix B).

8 J. F. Wright, The Contribution of Overseas Savings to the Funded National Debt of Great Britain, 1750-1815, in: Economic History Review, 2nd series, 50 (1997), S. 657-674.

9 P. G. M. Dickson, The Financial Revolution in England. A Study in the Development of Public Credit, 1658-1756, London 1967, S. 322.

10 H. V. Bowen, From Supranational to National. Changing Patterns of Investment in the British East India Company, 1750-1820, in: Bob Moore / Henk van Nierop (Hg.), Colonial Empires Compared. Britain and the Netherlands, 1750-1850, Aldershot 2003, S. 131-144.

11 Marten Gerbertus Buist, At Spes Non Fracta, Hope \& Co., 1770-1815, Merchant Bankers and Diplomats at Work, The Hague 1974, S. 20 .

12 This, at least, is the inference of John Roberts letter to Arthur Conran of Rotterdam, written from London on 1 Sept. 1752, The National Archives of the United Kingdom, Kew (henceforth TNA), Treasury Papers (Royal African Company), T 70/1478, fo. 3.

13 National Archives of Scotland, Edinburgh, Miscellaneous Gifts and Deposits, Campbell of Inverneill Papers, GD 1/6/2/2, Archibald Campbell to Directors of the East India Company, 2 Dec. 1786. 
smuggled goods detected on board East Indiamen between 1762 and 1771 included foreign textiles, wines, guns, steel, lead, iron, and copper, taken onto the ships at various points in their voyage to Asia - in the Channel, at continental ports such as Lisbon and Cadiz, and at Madeira, Tenerife, or the Cape Verde Islands. ${ }^{14}$

Commodities from continental Europe probably arrived in the largest quantities in Britain's North American and West Indian territories. Some entered the British colonies by unofficial routes, brought directly from northern European ports such as Amsterdam and Hamburg, or as a result of illicit trade between the North American mainland and the foreign West Indies, or of exchanges between British and other European islands in the Caribbean. ${ }^{15}$ Others arrived on British or colonial ships, after having passed first through a British port, in the manner prescribed by the seventeenth-century trade regulations known as the Navigation Acts. Many text-book statistical snapshots obscure the importance even of legal trade: continental European re-exports are often subsumed in the official figures for British exports. ${ }^{16}$ If we focus on the items in the list of re-exports that almost certainly came from continental Europe and add the value of these together, we can see that the European proportion of total official English exports to America and Africa in 1772-1774 was probably somewhere around a fifth. ${ }^{17}$ The quantity of illegally imported continental goods is impossible to calculate, though contemporary accounts nearly all suggest that it was considerable. $^{18}$

Textiles and clothing were prominent amongst the continental European commodities imported into the Atlantic colonies. "An Account of all Foreign Goods and Produce" legally imported into British North America during 1769, drawn up for the chancellor of the exchequer, includes German, Dutch, and Russian linens, Silesian and Dutch lawns, and Italian silks. ${ }^{19}$ Colonial records similarly demonstrate that continental European textiles and clothing items had penetrated British imperial markets. A few examples should suffice. Governor James Glen of South Carolina noted in 1749 the large numbers of Linnens of all kinds consumed in his colony, many of

14 H.V. Bowen, Privilege and Profit. Commanders of East Indiamen as private Traders, Entrepreneurs and Smugglers, 1760-1813, in: International Journal of Maritime History 19 (2007), S. 43-88, hier S. 63ff.

15 For examples of this trade early in the century, see Christian J. Koot, Empire and Periphery. British Colonists, Anglo-Dutch Trade, and the Development of the British Atlantic, 1621-1713, New York 2011, ch. 6. For the mid-century, see Huntington Library, San Marino, California, Invoice-book of Brand and Schuyler, 1744-53, HM 637, S. 17, 46, 50, 53f., 84ff. und $162 \mathrm{f}$.

16 See, e. g., Edwin J. Perkins, The Economy of Colonial America, New York 1980, S. 25-28, (Tables 2.1-2.3).

17 Jacob M. Price, The Imperial Economy, 1700-1776, in: P. J. Marshall (Hg.), The Oxford History of the British Empire, volume 2: The Eighteenth Century, Oxford 1998, S. 78-104, S. 102 (Table 4.5).

18 See, e. g., the view of Thomas Whately, a treasury secretary in the early 1760s, The Regulations Lately Made Concerning the Colonies, and the Taxes Imposed upon Them, Considered, London 1765, S. 92.

19 Bodleian Library, Oxford, MS North c. 83, fos. 17-24. 
them German, and also the considerable quantitys of the fine Laces of Flanders, the finest Dutch Linnens \& French Cambricks. ${ }^{20}$ James Pinnock, a barrister on Jamaica, purchased Three $p^{r}$ French ribbed Silk Stockings at the end of December 1766, and a French Silk \& Silver Waistcoat in December 1769. ${ }^{21}$ A farmer in Chester County, Pennsylvania, included 4 Holland Shirts amongst the goods seized or destroyed when the British army passed through his neighbourhood in September 1777.22 The following year, a New York merchant sold a quantity of what he described as Oznebrigs, a British corruption of Osnabrücks, or German linens. ${ }^{23}$

Some of these items might not have been what they seemed. Textiles described as Oznebrigs or Osnaburgs were not always the Westphalian originals; Scottish and Irish linen-makers produced their own imitations. ${ }^{24}$ Even so, we can be confident that foreign linens sold well across the Atlantic. In 1753, according to a contemporary account, 6.8 million yards of them were re-exported from Britain, mainly to the colonies in North America and the West Indies. ${ }^{25}$ Nine years earlier, in 1744, William Beckford, a prominent Jamaican planter, had testified before the House of Commons that large quantities of German linens were consumed in the British Caribbean islands. Merchants from many different German states established themselves in London in the second half of the eighteenth century at least partly to facilitate access to British colonial markets. ${ }^{26}$

Nor were textiles and clothing the only continental goods sent to North America and the West Indies. Colonial sources such as diaries, letters, inventories, and adverts in newspapers refer to items such as German steel and Dutch crockery. ${ }^{27}$ The soap used in the British Caribbean, according to one account, came mainly from Marseilles, smuggled into the British islands from the neighbouring French possessions. British soap, the same source tells us, melted in the heat, and became totally

20 British Library, London (henceforth BL), King's MS 205, fos. 292-3, Glen's responses to questions asked by the board of trade.

21 BL, Cash-Account-book of James Pinnock, 1758-1810; Add. MS 33, 317, fos. 64 and 74.

22 Historical Society of Pennsylvania, Philadelphia, Chester County Miscellaneous Papers, Depredation Claim of Joel Bailey of West Bradford, 11 Sept. 1777.

23 New-York Historical Society, New York City, Bancker Papers, Account-book Blotter, Feb. 1778.

24 See, e.g., Bristol Record Office, Ashton Court Collection, Woolnough Papers, AC/WO 16 (4) b, Jamaica Accts 31 Decr 1747, which refers to 11 Scotch Oznab. 778 Yds. For Irish and Scottish linen exports to America and the West Indies, see Price, 1998 (wie Anm. 17), S. 87f.

25 BL, Walpole (Wolterton) Papers, Add. MS 74,053, fo. 148.

26 Margrit Schulte Beerbühl / Klaus Weber, From Westphalia to the Caribbean. Networks of German Textile Merchants in the Eighteenth Century, in: Andreas Gestrich / Margrit Schulte Beerbühl (Hg.), Cosmopolitan Networks in Commerce and Society, 1660-1914, German Historical Institute, Supplement No. 2, London 2011, S. 53-98, hier S. 57 und 59-74.

27 See, e.g., for German steel, Connecticut Courant, 13 May 1765; for Delftware, see Boston Public Library, Boston, Massachusetts, CH M.1.10.147, Account of damages to the Estate of John Hancock by the British Army during the siege of Boston, 26 Feb. 1777. 
unserviceable. ${ }^{28}$ Fruits, almost certainly of Mediterranean provenance, appear to have been imported into the colonies in large quantities from Britain. ${ }^{29}$ In about 1766, Peter Hasenclever, a German who had recently arrived in New Jersey from England, reported to the British government that imports from Spain, Portugal and Italy and the whole Mediterranean were chiefly Fruit, though he added oil, salt, and wine as other important items. ${ }^{30}$

Wine deserves particular note. Affluent colonials, rather than rely on locally produced rum, drank copious quantities of Portuguese wine, given preferential access to British colonial markets in recognition of the long-standing Anglo-Portuguese alliance. Lisbon wine was popular; ${ }^{31}$ but for those who purchased it, Madeira was more than just a drink; it was a status symbol. ${ }^{32}$ German and Spanish wines also circulated freely; according to a visitor to Philadelphia in 1750, they were obtainable in all taverns. ${ }^{33}$ French wines, despite their expense, seem to have reached colonial consumers, too. Newspaper adverts demonstrate the ready availability of claret, the English name for red Bordeaux; ${ }^{34}$ and the personal diaries and journals of many members of the colonial elite testify to its even readier consumption. ${ }^{35}$

But the main European contribution to Britain's empire came in human rather than material form. Continental European experts played an important role. The General Survey of North America, undertaken after the Seven Years War to map out the recently enlarged British possessions, was directed by two surveyor generals, both of whom came from continental Europe. Samuel Johannes Holland, a Dutchman, was in charge of the northern department, while Wilhelm Gerhard von Brahm, a former Bavarian officer, born in Coblenz, supervised the survey work in the south. Many of those who served under Holland and Brahm also came from continental Europe, such as the Prussian Charles (or Carl) Blaskowitz, and Bernhard Romans, a native of the Dutch Republic. ${ }^{36}$

28 BL, West Papers, Add. MS 34,736, fo. 205, Petition of Willoughby Marchant, n.d., but probably 1756.

29 Bodleian Library, MS North C. 83, fo. 22.

30 William L. Clements Library, Ann Arbor, Michigan, Shelburne Papers, Thoughts concerning America by Mr Hasenclever, $c .1766$.

31 See George Francis Dow (Hg.), The Holyoke Diaries, Salem, Mass. 1911, S. 22; for consumption at Harvard College in 1760.

32 David Hancock, Oceans of Wine. Madeira and the Emergence of American Trade and Taste, New Haven 2009.

33 Oscar Handlin / John Clive (Hg.), Journey to Pennsylvania by Gottlieb Mittelberger, Cambridge, Mass. 1960, S. 37.

34 See, e. g., Connecticut Courant, 6 May 1765, 3 March 1766.

35 See, e. g., Mabel L. Webber (ed.), Journal of Robert Pringle, 1746-1747, in: South Carolina Historical and Genealogical Magazine 26 (1925), 21, 22; Jack P. Greene (ed.), The Diary of Colonel Landon Carter of Sabine Hall, 1752-1778, 2 vols., Charlottesville 1965, ii. 671 and 737.

36 For Holland, see Stephen Hornsby, Surveyors of Empire. Samuel Holland, J.F. W. Des Barres, and the 
Another example of where continental expertise was used to support British imperial efforts is the presence of the German naturalists Johann Reinhold Forster and his son Georg on James Cook's second voyage of discovery in the Pacific in 1772-1775. To add to the European flavour of the enterprise, Forster senior took on as an assistant the Swedish naturalist Anders Sparrman when Cook's vessels docked at Cape Town. Johann Reinhold had already published work in English on the animals, birds, and insects of North America, and when father and son returned from Cook's voyage, Georg produced a massive two-volume account, based on the detailed records of their travels, published with a British readership in mind.$^{37}$ Some of the Forsters' specimens collected on the voyage were sent to Oxford in January 1776, and subsequently displayed in the Ashmolean Museum. Forster senior's Scottish ancestry, and his coming to England in the seventeen-sixties, admittedly made him an ambiguous figure; he described himself as appertaining equally to the Brittish \& the German nation. ${ }^{38}$ Even so, Forster's German credentials were clear; born in Prussia, he was an ordained Lutheran pastor, educated at Berlin and Halle.

More significant, at least numerically, were the continental European sailors who served on British ships. Royal Navy vessels took on board trained mariners, regardless of their nationality. In the War of American Independence, the Danish consul in London complained of the great Number of our Seamen pressed. ${ }^{39}$ Muster lists suggest that Swedes, Dutchmen, Germans, and Portuguese as well as Danes helped to crew British warships. But we should not exaggerate the numbers involved: most ships had only a relatively small continental European contingent on board; probably no more than about six per cent, if a sample of ships' musters at the time of the American war is an accurate guide. ${ }^{40}$

Continental sailors were much more numerous on trading ships, especially in wartime, when merchant captains sought to replace British and Irish crew members transferred into the navy. ${ }^{41}$ As mariners' wage rates rose, large numbers of foreign

Making of The Atlantic Neptune, Toronto 2011. For the survey as a whole, see Alexander James Cook Johnson, Charting the Imperial Will. Colonial Administration and the General Survey of British North America, 1764-1775, University of Exeter PhD dissertation, 2012.

37 Georg Forster, A Voyage around the World, in His Majesty's Sloop, Resolution, Commanded by Capt. James Cook, during the Years 1772, 3, 4, and 5, 2 vols., London 1777.

38 National Library of Scotland, Edinburgh, Robertson-MacDonald Papers, MS 3943, fo. 55, Forster to [William Robertson], 16 Dec. 1777.

39 TNA, Admiralty Papers, ADM 1/5118/21, fo. 520.

40 Stephen Conway, The British Isles and the War of American Independence, Oxford 2000, S. 36. Unfortunately, comparable data is not available for earlier in the century.

41 David J. Starkey, War and the Market for Seafarers in Britain, 1736-1792, in Lewis R. Fischer / Helge W. Nordvik (Hg.), Shipping and Trade, 1750-1950. Essays in International Maritime Economic History, Pontefract 1990, S. 25-42, hier S. 34f.; Peter Earle, Sailors. English Merchant Seamen, 1650-1775, London 1998, S. 203. 
sailors flocked to British ports from Scandinavia, the Dutch Republic, and north Germany. A good many of them were probably employed on routes with which they were familiar - particularly on the short crossing from southern England to the Low Countries, and on voyages on the North Sea and into the Baltic. But continental Europeans also joined the crews of ships sailing across the Atlantic. The wages-book for the Clifton, a merchant vessel whose sailors were discharged in Devon in the spring of 1762, after a trip to Barbados, includes names that are clearly not British. Eric Ferdinand Pape and Matthew Thesia, probably Germans, both left the ship at Barbados. The man described as Godfrey Strag was almost certainly German, too; when he signed the book to acknowledge receipt of his pay, he wrote his name as Gott Fried Strag. ${ }^{42}$

Settlement of the British colonies in North America relied heavily on Europeans from beyond the British Isles. By the end of the seventeenth century, parts of New England were already densely populated by people who could trace their origins back to the first English colonists; but further south, in the middle and southern provinces, development depended upon attracting large numbers of immigrants. Some non-British Europeans were already in the colonies when the eighteenth century began: Dutch descendants of the original New Netherland settlers, Swedish-speakers whose forefathers had established New Sweden, and French Huguenots, who had arrived in New York and South Carolina after the Revocation of the Edict of Nantes in 1685.43

But it was in the eighteenth century that continental European migration to North America took off. The middle colonies, especially Pennsylvania, were the most popular destination for incomers, but other areas attracted significant numbers. In the seventeen-thirties, Protestants from Salzburg founded Ebenezer, in Georgia, and Swiss Protestants established themselves at Purrysburg, South Carolina. ${ }^{44}$ The end of the War of the Austrian Succession in 1748 saw another surge of continental European Protestants coming to America, from Nova Scotia in the north to Georgia in the south. After the Seven Years War, British promoters of settlement in newly acquired Florida, ceded by Spain, encouraged Greeks, Corsicans, Italians, and Minorcans to come to the infant British colony. New Smyrna, a settlement on the Atlantic coast of East Florida, had a short-lived existence as a Greek enclave between 1768 and 1777.45

42 Bristol Record Office, Ashton Court Collection, Munckley Papers, AC/MU 1 (9).

43 For the Huguenots, see Paula Wheeler Carlo, Huguenot Refugees in Colonial New York, becoming American in the Hudson Valley, Brighton 2005; and Bertrand van Ruybeke, From Babylon to Eden. The Huguenots and their Migration to Colonial South Carolina, Columbia SC 2006.

44 For the Salzburgers, see Thompson, 2006 (wie Anm. 1); for Purrysburg, Arlin C. Migliazza, To Make This Land Our Own. Community, Identity and Cultural Adaptation in Purrysburg Township, South Carolina, 1732-1865, Columbia SC 2007.

45 Bernard Bailyn, Voyagers to the West. Emigration from Britain to America on the Eve of the Revolution, 
French Protestants, from near Bordeaux, whom the governor of East Florida hoped to lure to his province, ended up settling in South Carolina. ${ }^{46}$

The largest number of continental European arrivals in the North American colonies, both before and after the Seven Years War, came from Germany. They comprised but a small part of the outward flow of people from the Holy Roman Empire; more went in other directions - north, east, and south within Europe, or to Asia in the service of the Dutch East India Company - than went west to settle across the Atlantic. ${ }^{47}$ But Germans made up a significant proportion of the migrants coming to British North America. So great were the numbers over the course of the century that German-speakers formed about ten per cent of the settler population by the eve of the American Revolution. They were particularly concentrated in Pennsylvania, where a third of the white people were of German origin. ${ }^{48}$

Yet the most important European human contribution to British imperial activity arguably came in military form. ${ }^{49}$ Most of the common soldiers in the East India Company's European forces were British or Irish, though scattered contemporary testimony suggests that a far from negligible number were from other European countries. ${ }^{50}$ We know that Swiss troops served the East India Company in the seventeen-fifties, under the command of their own officers. ${ }^{51}$ Nearly thirty years later, in 1782, two Hanoverian regiments sailed to India to reinforce the beleaguered royal and company troops, who were facing a powerful enemy in the form of Haidar Ali of Mysore, supported by a French expeditionary army. The Hanoverians were still on the subcontinent ten years later; and when their regiments were recalled some of the

London, 1987, S. 451-461.

46 Haines Hill, Berkshire, Colleton, Garth, and Godsal Family Papers, Box 23, Charles Garth letter-books, Garth to South Carolina Assembly's Committee of Correspondence, 24 Oct., 20 Nov. [1763]; National Archives of Scotland, Macpherson Grant of Ballandalloch Papers, GD 494/1/2, James Grant to John Savage, 12 July 1765 .

47 See David Eltis, Introduction, in: Eltis (Hg.), Coerced and Free Migration. Global Perspectives, Stanford CA. 2002, esp. S. 17, for every German that moved to the Americas, nine migrated in the opposite direction.

48 A. G. Roeber, The Origins of Whatever Is Not English among Us. The Dutch-speaking and German-speaking Peoples of Colonial British America, in: Bernard Bailyn / Philip D. Morgan (Hg.), Strangers within the Realm. Cultural Margins of the First British Empire, Chapel Hill 1991, S. 220-283, hier S. 244.

49 For more on this, see Stephen Conway, Continental European Soldiers in British Imperial Service, c.1756-1792, English Historical Review, 129 (2014), S. 79-106.

50 BL, India Office Records, E/1/55, fo. 406, Richard King to Peter Michell, 18 April 1771; and the comments of Lord Cornwallis, in November 1786, ibid., Home Misc./389, p. 319. For British enlistments, see H. V. Bowen, The East India Company and Military Recruitment in Britain, 1763-71, Bulletin of the Institute of Historical Research 59 (1986), S. 78-90; for the Irish contribution, see Thomas Bartlett, The Irish Soldier in India, 1750-1947, in: Michael Holmes / Denis Holmes (Hg.), Ireland and India. Connections, Comparisons, Contrasts, Dublin 1997, S. 12-28, hier S. 14 (Table 2.1).

51 See, e. g., BL, India Office Records, E/4/861, S. 67, 218, 333, Directors of the East India Company to the President and Council at Fort St George, 19 Dec. 1753, 24 Jan. and 29 Nov. 1754. 
soldiers volunteered to transfer into company service. ${ }^{52}$ When they first arrived in India, the two battalions of Hanoverians joined seven British army infantry battalions and a cavalry regiment. The Hanoverian battalions, each of 1,000 officers and men, were stronger than the British, so we can assume that the Germans comprised well over twenty per cent of the non-company forces in India at that time. ${ }^{53}$

At the beginning of the War of American Independence, George III in his capacity as elector also lent Hanoverian regiments to help garrison Minorca and Gibraltar, freeing up British regiments for service elsewhere. Proportionately, German soldiers made a much bigger contribution in the Mediterranean than in India; in 1776, five Hanoverian battalions garrisoned Gibraltar and Minorca, together with a total of six British. ${ }^{54}$ British military capacity benefited from continental European manpower in North America, too. German, Swiss, and Dutch officers obtained commissions in the Royal American Regiment, raised in 1756 after the British Parliament gave a special dispensation from the requirements of the Act of Settlement of 1701, which debarred all but the crown's subjects from holding civil or military office. ${ }^{55}$ In the Seven Years War, and in the subsequent peace, the regiment's rank and file included many Germans recruited in Germany. ${ }^{56}$ When the American rebellion broke out in 1775, German enlistment into the Royal Americans was pursued again with vigour. ${ }^{57}$ At the same time, German military entrepreneurs agreed to provide recruits to fill other understrength British regular infantry battalions; the most important of these contractors, the Hanoverian Lieutenant-Colonel Georg Heinrich Albrecht von Scheither, eventually supplied nearly 2,000 soldiers for various British regiments serving in North America. ${ }^{58}$

The most substantial German military contribution, however, both in the American war and more generally, came in the form of the established units hired from a variety of German states. Known generically as the Hessians, these German auxiliaries

52 Ibid., E/4/879, S. 255. See also Chen Tzoref-Ashkenazi, German Voices from India. Officers of the Hanoverian Regiments, in: East India Company Service, South Asia. Journal of South Asian Studies 32 (2009), S. 189-211.

53 For the royal forces in India, see P. J. Marshall, The Making and Unmaking of Empires. Britain, India, and America, c.1750-1783, Oxford 2005, S. 220.

54 For the British troops, see Houlding 1981 (wie Anm. 7); for the Hanoverians, see Rodney Atwood, The Hessians. Mercenaries from Hessen-Kassel in the American Revolution, Cambridge 1980, S. 25.

55 Augustine Prévost, e.g., who became a major in the Royal Americans, had been a captain in a Swiss regiment in the Dutch army, see National Army Museum, Chelsea, 6106-40-1-2. Other French-speaking Swiss Protestants included Prévost's brother Jacques-Marc, Henri Bouquet, and Frederick Haldimand.

56 For German recruits arriving at New York from Hamburg in 1756, see Huntington Library, Loudoun Papers, LO 1607. For the raising of 300 Germans in 1766, see Joseph Redington (Hg.), Calendar of Home Office Papers of the Reign of George III, 1766-1769, London 1879, S. 54.

57 For one contractor's account, see John Savage, The Case of Major John Savage, London 1785.

58 TNA, War Office Papers, WO 4/99, S. 198. For Scheither's contract generally, see the documents collected in WO 43/405. 
came not only from Hessen-Kassel and Hessen-Hanau, but also from Brunswick and Waldeck, and later from Anhalt-Zerbst and Ansbach-Bayreuth. Initially, the British government intended to use the Hessian and Brunswick units in the same way as they employed the Hanoverians sent to Gibraltar and Minorca - to relieve British troops for service in America. Lord North, the prime minister, planned to send the Germans to Ireland, and dispatch British regiments in Ireland across the Atlantic. But, fearing Protestant Irish objections, he decided instead to use the Germans in North America. ${ }^{59}$ Originally they seem to have been earmarked for garrison duties, freeing up the maximum number of British soldiers to fight the rebels; but very quickly this idea was abandoned, and most of the German auxiliaries were employed as a field force, alongside the British regulars. By the closing years of the war, the Hessians comprised some thirty-seven per cent of the British army in North America. ${ }^{60}$

\section{II.}

How did decision-makers in London view continental European participation in the empire? Some forms of involvement were beyond their oversight, or even took place without their knowledge. But in many areas the British state sought to shape and control continental European penetration of its overseas possessions. Mercantilist ideas about how to achieve national advantage led British governments to seek to limit the quantity of continental European products entering imperial markets. A good example of this is the attempt made - without great success - to reduce colonial consumption of continental European textiles, especially linens, after the Seven Years War.

The seventeenth-century Navigation Acts envisaged colonies as appendages of the national community, established to boost national prosperity and national power. The 1663 Navigation Act stipulated that continental European products could be sent to the English colonies only once they had passed through an English port. The intention was partly to levy customs duties that would provide the crown with an income, but also to increase the cost of the items for colonial consumers, and so incline the settlers to purchase similar English manufactures instead. During the course of the eighteenth century, import duties on foreign textiles steadily rose, especially in wartime, when the state needed extra revenue. A five per cent increase was imposed in 1748, at the end of the War of the Austrian Succession, and another five per cent added in 1759, during the Seven Years War. ${ }^{61}$ But cheaply produced German linen

59 TNA, State Papers Ireland, SP 63/437B, fos. 36-7, 39, 46.

60 Atwood, 1980 (wie Anm. 54), S. 257 (Appendix D).

61 See N. B. Harte, The Rise of Protection and the English Linen Trade, 1690-1790, in: Ders. / K. G. Ponting (Hg.), Textile History and Economic History, London, 1973, S. 74-112, hier S. 75-84. 
exports to North America and the West Indies continued to thrive, partly because many were smuggled into the colonies without coming through a British port and paying duties, and partly because foreign linens that reached the colonies via Britain were subject to a drawback, or repayment of part of the import duty, which British merchants could claim if they re-exported the linens.

British politicians appear to have considered removing the drawback at various points in the eighteenth century. The mercantile community divided on the issue, but those who opposed ending the drawback seem to have had the most influence, at least until the end of the Seven Years War. In the seventeen-fifties, for instance, Dennys de Berdt, a prominent London merchant, argued that the drawback served British interests. Without it, he claimed, smuggling to North America and the West Indies would probably increase. Revenue would be lost on the import of foreign linens. And, most importantly, foreigners would earn less for their linens and therefore be unable to buy so many British woollen goods. They might even start producing more woollens of their own, and sell these across the Continent, reducing the consumption of British wool products still further. ${ }^{62}$

British politicians were less persuaded by such arguments after the Seven Years War, when access to European markets became more restricted as a result of new tariffs imposed by continental governments. ${ }^{63}$ To successive post-war ministries, the colonies were the one reliable market for British manufactures; it followed that foreign competition should be strongly discouraged. Historians mainly remember George Grenville's Revenue Act of 1764 for its changes to the duty on foreign molasses (semi-refined sugar) entering the North American colonies; but besides increasing the money coming into the government's coffers, the act was designed to limit the flow of continental European linens entering North America and the West Indies. The new legislation ended the re-export drawback and imposed new duties on foreign cloth sent to the colonies.

Grenville's Revenue Act attracted some opposition, but almost exclusively on the issue of the most appropriate rate for the molasses duty. Very few MPs questioned Grenville's attempt to reduce foreign linen sales in America, and most of those who did express concern were not regular opponents of the government. Richard Glover, who had important mercantile connections, was probably the most vocal critic of Grenville's proposal to remove the drawback, and yet he was usually a supporter of the ministry. He argued, as de Berdt had done in the seventeen-fifties, that smuggling would be inadvertently boosted and, in a new point, that colonial manufacture

62 BL, Walpole (Wolterton) Papers, Add. MS 74,053, fos. 48 and 113-14, de Berdt to Horatio Walpole, 27 Feb. and 9 April 1755.

63 De Berdt continued to put the case for the drawback, and the dangers of removing it, see Huntington Library, Stowe Collection, Grenville Papers, STG Box 21, de Berdt to [Thomas Fonnereau], 21 March 1764. 
of linens would be encouraged. ${ }^{64}$ But politicians associated with the parliamentary opposition tended to agree with the government, at least on the case for reducing foreign linen consumption in the colonies. William Baker, a supporter of the out-ofoffice Duke of Newcastle, effectively endorsed Grenville's approach. So, too, did John Huske, another MP associated with the opposition, who argued that the removal of the drawback on foreign linens was a bounty to our own manufactures. ${ }^{65}$

The next government, led by the Marquis of Rockingham, set about reversing many of Grenville's initiatives. Most famously, the new administration repealed Grenville's American Stamp Act, which had caused enormous uproar in the colonies and threatened to bring transatlantic trade to a stand-still. At the same time, Rockingham and his colleagues undertook a radical overhaul of the 1764 Revenue Act, reducing the charge on foreign molasses entering the North American colonies and introducing free ports in the West Indies. But in one important respect Grenville's regulatory edifice was left intact. The new government's Revenue or Plantation Duties Act of 1766 did not overturn the previous ministry's attempts to reduce colonial consumption of continental European manufactures. The drawback on foreign linen re-exports was not restored, and the 1766 act maintained Grenville's new duties on linens imported into the colonies.

Two very different governments, then, had very much the same perspective on the need to keep the colonies as captive markets for British manufactures. Their immediate successors took the same view. Charles Townshend, chancellor of the exchequer in the government led by the Duke of Grafton, toyed with the idea of making it easier for southern European fruit, oil, and wine to enter the colonies. Townshend planned to impose a duty on these imports, but at the same time reduce their price to colonial consumers by allowing them to be shipped directly to North America, rather than come through a British port. ${ }^{66}$ In the end, Townshend retreated in the face of parliamentary opposition. But even if he had proceeded with his original plan, his liberality was distinctly limited. Fruit, oil, and wine were not direct competitors for British manufactures. At no stage does Townshend appear to have contemplated any change in the duty chargeable on German and other continental textiles imported into British America. Lord North, chancellor of the exchequer after Townsend died, also made no attempt to reduce the fiscal discrimination against foreign linens intro-

64 Hampshire Record Office, Winchester, Malmesbury Papers, 9M73/G713, S. 116, Parliamentary Diary of James Harris, 23 March 1764. For earlier indications of Glover's opposition to the removal of the drawback, see S. 100 und 102.

65 P. D. G. Thomas (Hg.), The Parliamentary Diaries of Nathaniel Ryder, 1764-7, Royal Historical Society, Camden Miscellany 23, 4th series, volume 7, London 1969, S. 236 und 238.

66 Thomas (Hg.), 1969 (wie Anm. 65), S. 344; Dalkeith House, Midlothian, Buccleuch and Queensberry Muniments, Townshend Papers, Box VIII, bundle 31, includes documents on Proposed duties on wine, oil, \& fruit imported into America. 
duced in 1764 and confirmed in 1766. Indeed, while North was first minister, the discrimination increased; in 1771 the subsidy on the export of certain types of British linens, introduced in 1743 , was extended to new sorts of fabric, providing an added advantage to British products in colonial markets. ${ }^{67}$

Given these efforts to exclude foreign manufactures, it might seem odd that British governments generally welcomed continental European manpower. An exclusionary approach in one area might be expected to have encouraged the same in others. After all, many Britons outside government circles were far from comfortable about the presence of continental Europeans in the empire. Benjamin Franklin, in an essay written in 1751, famously criticized the large number of German settlers in Pennsylvania, which he claimed was losing its English character. ${ }^{68}$ Other commentators doubted the reliability of outsiders. Captain James Douglas of the Royal Navy, for instance, reported from the Caribbean in 1760 that the deserters from his vessel were all Foreigners, who were now serving in the Enemy's Privateers. ${ }^{69}$ In the next war, British critics readily attributed the overwhelming Hessian defeat at Trenton in December 1776 to the German-ness of the auxiliary troops. ${ }^{70}$

Ministers and administrators in London no doubt had their own prejudices, but these are not readily apparent in the official record. The one exception to this general rule is religious rather than national. Before and during the Seven Years War, British governments regarded continental Catholics as unsuitable, at least as settlers or soldiers, fearing that they would be tempted to support their French and Spanish co-religionists. After 1763, when the Protestant cause seemed to have triumphed in Europe and Catholicism appeared less threatening, even official hostility to Catholic involvement diminished. In general, both before and after the Seven Years War, British governments took the view that national sentiment should be subordinated to national interests; if the state needed manpower, it had no hesitation in turning to the rest of Europe to provide it.

Consider the case of continental European mariners. Dutch, German, and Scandinavian sailors, as we have seen, flocked to serve on board British merchant ships in wartime, attracted by the high wages. But we should not suppose that their recruitment was simply a natural consequence of the workings of an international free market in maritime labour. The British state tightly regulated the manning of merchant vessels to promote national advantage. The Navigation Act of 1660 stipulated that only English ships could carry goods between English territories and that

67 Harte, 1973 (wie Anm. 61); S. 98f..

68 Leonard W. Labaree u. a. (Hg.), The Papers of Benjamin Franklin (39 vols. to date), New Haven, 1959-, S. iv. 234.

69 National Maritime Museum, Greenwich, Sir James Douglas Papers, DOU/4, Douglas to John Clevland, 14 Dec. 1760.

70 See, e. g., New-York Historical Society, Andrew Elliot Letters, Andrew Elliot to his brother, 3 Jan. 1777. 
three-quarters of the crew must be subjects of the crown. The aim was to secure a great reserve of trained mariners, who could be conscripted into the Royal Navy in time of war. Eighteenth-century British governments, however, recognized that if British sailors were transferred into the navy, then the needs of the merchant marine had to be met from elsewhere. Large numbers of foreign seamen were able to join British ships in wartime only because the government secured parliamentary approval for a temporary suspension of the manpower requirements of the 1660 Navigation Act at the beginning of every conflict in which Britain was a participant. ${ }^{71}$

In the case of the merchant marine, British governments called on foreign help only in wartime; once hostilities ended, the restrictions of the 1660 Navigation Act came back into force. By contrast, ministers and officials in London believed that they had to offer more consistent encouragement to secure foreign assistance in settling British North America. A good deal of the movement of people across the Atlantic, it should be said, owed little or nothing to the actions of the British state. Most Germans who made the journey to the middle colonies arrived as a result of private engagements between colonial landowners and employers on the one hand and recruiting agents and ships' captains carrying the migrants on the other. ${ }^{72}$ Colonial governments also played a part. South Carolina's assembly passed a tax on slave sales in 1741, the revenue from which was devoted to subsidizing the settlement of continental European Protestants in the colony. ${ }^{73}$ The same assembly later underwrote the expenses of a Charleston merchant house that shipped in French Protestant refugees. ${ }^{74}$

But governments in London did not rely on private or local initiatives; they offered their own inducements. In 1740, a Naturalization Act, sponsored by the ministry, gave foreign Protestants who had resided in the North American colonies for seven years the same rights as the king's natural-born subjects, so long as the migrants swore an oath of allegiance to their new monarch. ${ }^{75}$ The intention was clearly to encourage further foreign migration. In the early seventeen-fifties, the British government even paid for the voyage of German and Swiss settlers to Nova Scotia, and then provided them with provisions on their arrival. ${ }^{76}$ The expense proved so considerable

71 See the following Acts of Parliament, 13 Geo. II, c.3, $\$ 1$ (1740); 28 Geo. II, c. 16 (1755); 16 Geo. III, c. 20 (1776); 33 Geo. III, c. 26 (1793).

72 See, e. g., Günter Moltmann, The Migration of German Redemptioners to North America, 1720-1820, in: P. C. Emmer (Hg.), Colonialism and Migration. Indentured Labour before and after Slavery, Dordrecht 1986, S. 105-122.

73 See TNA, Colonial Office Papers, CO 5/373, fos. 206-11, An Account of Cash Receiv'd and Paid by John Dart Commissary General by the Appropriation Law for Settling of Poor foreign Protestants in the Townships of South Carolina, 1743-50, which suggests more than $£ 25,000$ was spent for the purpose. A revision of the law in 1752 lowered the bounty, due to concerns about the cost (CO 5/374, fo. 60).

74 Ibid., CO 5/378, fo. 38, William Bull to the Lord Commissioners of Trade and Plantations, 24 Oct. 1764.

7513 Geo. II, c. 7.

76 See, e. g., Journal of the Commissioners for Trade and Plantations from January 1749-1750 to December 
that this scale of generosity was not repeated, but after the Seven Years War, government money was again used to help cover the costs of bringing French Huguenots to South Carolina and Greeks and other Mediterranean peoples to East Florida. ${ }^{77}$ In the case of the Greeks, the government even agreed to loan a de-commissioned naval vessel to the private projector who appealed for help to transport his migrants to America. ${ }^{78} \mathrm{~A}$ more usual subsidy was the forgoing of potential tax income: British governments routinely allowed new settlers to pay no quit rents - a form of royal revenue - for up to ten years after their arrival. ${ }^{79}$

Why did British governments offer such encouragement to European migrants? Part of the explanation lies in the need to settle sparsely populated areas of the colonies. The British state had no need to stimulate German migration to Pennsylvania, which attracted large numbers of incomers, but the mid-eighteenth-century population of Nova Scotia in the north and Georgia in the south remained very small. In the former, most of the inhabitants were Mik'maq Indians or French Acadians; apart from the British military garrison, no more than a few hundred British colonists lived in the province. ${ }^{80}$ Georgia's trustees reckoned about the same time that its white population was a mere 1,700 strong. ${ }^{81}$ Even in neighbouring South Carolina, an English colony since the sixteen-sixties, the governor thought in 1749 that there were no more than 25,000 settlers. $^{82}$

Increasing the settler population would improve the security of the colonies. The government's decision to subsidize foreign Protestant settlement in Nova Scotia owed much to a desire to make the colony more defensible in the case of a French attack. Security was an important consideration elsewhere. In many places, natives posed a threat on the frontier; additional settlers would reduce that threat. ${ }^{83}$ In the southern plantation colonies, slave insurrection was a constant white anxiety. The introduction of rice cultivation into South Carolina at the very end of the seventeenth century created a great surge in slave numbers. By 1708 the colony had a black majority; hence the keenness of the local assembly to promote the settlement of foreign

1753, London 1932, S. 42, S. 46, S. 50f., S. 66, S. 72, S. 82, S. 183, S. 194, S. 204, S. 210, S. 221, S. 247 , S. 392 .

77 See TNA, Colonial Office Papers, CO 5/540, fo. 12, for the French Huguenots; and ibid., CO 5/548, fos. $158-162$, for the Greeks.

78 Ibid., CO 5/548, fos. 154-156.

79 See, e. g., TNA, CO 5/145, fo. 56, John Robinson to John Pownall, 16 July 1772.

80 For lists of the settlers receiving provisions in 1749 and 1750, see ibid., Treasury Papers, T 1/336/42-5 and T 1/337/83. For Nova Scotia more generally, see Geoffrey Plank, An Unsettled Conquest, The British Campaign against the Peoples of Acadia, Philadelphia 2001.

81 TNA, Colonial Office Papers, CO 5/656, fo. 201, Georgia Trustees' memorial to the king, n.d., but c. 1750.

82 BL, King's MS 205, fo. 296.

83 See, e.g., South-Carolina Gazette, 27 Sept. 1752, report of Gov. James Glen's speech to the assembly. 
Protestants, who would reduce the racial imbalance. Hence, in part, too, we can surmise, the British government's willingness to encourage French, Swiss, and German migration to the colony.

British governments also recognized that many foreign settlers had qualities that made them particularly suitable for developing the colonies. The British state's subsidizing the costs of bringing Mediterranean peoples to East Florida can be explained by the settlers' reputed skills in cotton and silk production. ${ }^{84}$ The French Protestants from near Bordeaux who went to South Carolina in the seventeen-sixties offered knowledge of viticulture as well as silk manufacturing. ${ }^{85}$ Around the same time, a British secretary of state was well disposed to a project for settling in East Florida former gun-makers from Liege, on the grounds that they could establish a Manufactory of small Arms in their new American home. ${ }^{86}$ British sources rarely identify German settlers as having specialist skills, but they routinely describe them as industrious. ${ }^{87}$ According to a report drawn up for the government in 1771, the German settlers in the back country of South Carolina supplied Charleston with large quantities of flour and produced more than enough hemp for the cordage used on the province's merchant ships. ${ }^{88}$ Settlers of this kind would increase colonial production, which would benefit the metropolitan economy both by sending to Britain valuable raw materials and foodstuffs and by earning the export credits to afford an increasing quantity of British manufactured goods in return.

Foreign migrants had another great advantage in the eyes of British politicians and officials. They allowed the colonies to be populated without depleting Britain's own human capital reserves. A central tenet of mercantilist thought was that countries with large populations were stronger than countries with small populations. In this sense, Britain was at a great disadvantage compared with France, which throughout the eighteenth century had a population roughly double that of Britain and Ireland combined. During and just after wars, British ministers' awareness of this demographic deficit unsurprisingly increased. In 1762, when the South Carolina assembly was keen to encourage migration into the colony, its agent in London wrote that the British government was reluctant to see any new settlers come from its own country,

84 TNA, Colonial Office Papers, CO 5/548, fos. 156-8.

85 Haines Hill, Colleton, Garth, and Godsal Family Papers, Box 23, Charles Garth Letter-books, Garth to the South Carolina Assembly's Committee of Correspondence, 9 July 1763.

86 TNA, Colonial Office Papers, CO 5/540, fo. 74, Earl of Sandwich to the Lords Commissioners of Trade and Plantations, 13 July 1764.

87 See, e. g., National Archives of Scotland, Macpherson Grant of Ballandalloch Papers, GD 494/1/2, James Grant to Thomas Thoroton, 1 Sept. 1766; John Huddlestone Wynne, A General History of the British Empire in America, volume 2, London 1770, S. 307; Francis Harper (Hg.), Travels in Georgia and Florida, 1773-74. A Report to Dr John Fothergill, Transactions of the American Philosophical Society 33, Pt. II (1943), S. 136.

88 BL, King's MS 210, fo. 3. 
which was so drain'd of men by the Seven Years War that we have hardly sufficient for the Manufacture and Husbandry of this Island. He added that for internal security reasons the government in Dublin was even more unwilling to see any diminution in the Protestant population of Ireland. ${ }^{89}$

Similar manpower considerations encouraged London governments to look favourably on the recruitment of Swiss, Dutch, and above all German soldiers for service in the British Empire. Britain's manpower supplies were limited, especially compared with France's, even after the Scottish Highlands and then Catholic Ireland had been subjected to increasingly heavy recruiting. Nevertheless, we would be mistaken if we concluded that the British state welcomed continental European soldiers simply because it had no alternative source of manpower to tap. Imperial populations provided a considerable reinforcement to British and Irish military resources in the wider world, particularly in the form of provincial regiments in the American colonies, or the much more numerous native contribution to the manning of the East India Company's army. If it were just a question of numbers, these imperial troops could provide the support that British military forces needed. But as with foreign settlers, quality was as important to British governments as quantity. Foreign Protestant officers brought into the Royal American Regiment offered the language skills necessary to recruit German settlers in the colonies, but also technical expertise as engineers and cartographers. Several went on to glittering careers as imperial soldiers and administrators; the Swiss-born Frederic Haldimand, for instance, became governor of Quebec. British ministers probably saw Germans troops in particular as a valuable addition to British strength. If German settlers were industrious, German soldiers were solidly reliable. ${ }^{90}$ They were European professionals, who used the same tactics as British regular soldiers, and shared with them the same military culture; they were the most natural supplement, in other words, to British military forces deployed across the empire. ${ }^{91}$

89 Haines Hill, Colleton, Garth, and Godsal Family Papers, Box 23, Charles Garth Letter-books, Garth to the South Carolina Assembly's Committee of Correspondence, 30 Sept. 1762.

90 See, e. g., Frauke Geyken, The German Language is Spoken in Saxony with the Greatest Purity, or English Images and Perceptions of Germany in the Eighteenth Century, in: Joseph Canning / Hermann Wellenreuther (Hg.), Britain and Germany Compared. Nationality, Society, and Nobility in the Eighteenth Century, Goettingen 2001, S. 37-70, hier S. $48 f$.

91 See, e. g., Stephen Conway, The British Army. Military Europe, and the War of American Independence, William \& Mary Quarterly, 3rd series, 67 (2010), S. 69-100; Conway, 2011 (wie Anm. 1). 


\section{III.}

Continental European involvement in the eighteenth-century British Empire, then, was greater than most imperial historians acknowledge. That involvement was not simply a consequence of the inability of the British state to maintain an exclusionary empire for national advantage. The limited reach of London governments did indeed contribute to the ready availability of many continental manufactured goods in the Atlantic colonies; despite the best efforts of ministers and officials, illegal trade simply could not be curbed. But other forms of European involvement stemmed not from the failure of the British state to impose its will, but at least partly from its success. Continental manufactures might have been unwelcome to British governments, but continental human capital was not. Foreign experts, sailors, settlers, and soldiers all played a significant part in the making of the British Empire, and with the active encouragement of ministers and officials in London. British governments had no qualms about using transnational means to secure national imperial ends. 